\title{
The Effect of Consumption on Economic Growth in Asia \\ Hae Kim*
}

Department of International Relations, Troy University, 600 University Ave, Troy, AL 36082, USA

*Corresponding author: Hae Kim, Department of International Relations, Troy University, 600 University Ave, Troy, AL 36082, USA, Tel: 713-500-6759; Fax: 713-500-5495; E-mail: eunhaen@troy.edu

Rec date: July 11, 2017; Acc date: August 02, 2017; Pub date: August 09, 2017

Copyright: (c $2017 \mathrm{Kim} \mathrm{H}$. This is an open-access article distributed under the terms of the Creative Commons Attribution License, which permits unrestricted use, distribution, and reproduction in any medium, provided the original author and source are credited.

\begin{abstract}
The purpose of this paper is to assess the effect of consumption on economic growth in Asia based on 52 countries/territories, while the effects of other variables that are also assumed to affect economic growth are statistically controlled. For this purpose, this study explores different patterns of economic growth based on 18 'economic' variables, including the consumption. There are six patterns of economic growth identified: (1) consumption-driven; (2) export-led; (3) oil-rich; (4) savings-based; (5) government (public) spending-based and (6) domestic investment-based. Empirical evidences show that the dominance of the consumption-driven economic growth in Asia cannot be denied. The patterns found in Asia are shared with the rest of the world economy, yet there were some 'uniqueness' to the Asian patterns, which feature as follows: (1) high savings; (2) a large defense spending affected by both oil-richness and politics (authoritarian government); and (3) high 'national' global competiveness worldwide. And any negative 'uniqueness' to the Asian economy should be reassessed in light of the 'multidimensionality' of successful consumption-driven economic growth model as empirically proven in Asia.
\end{abstract}

Keywords: Consumption; Driven economy; Uniqueness to Asian economy; Export-led economy; Oil-rich economy; Factor analysis

\section{Introduction}

The purpose of this paper is to assess the effect of consumption on economic growth in Asia based on 52 countries. It assesses the effect of the consumer-spending/consumption on economic growth while so many other theories of economic growth and variables thereof such as investment, export/trade, savings, oil, defense spending, for examples, are controlled. Many theories of economic growth are based on a single variable either as a cause of economic growth (GDP/PPP) or as a variable to assess its effect on the quality of life. These univariate approaches coalesced on a single-variable fail to identify a genuine 'independent' effect of an individual single variable on economic growth. Can economic growth in Asia be driven by consumer spending/consumption? What can be the effect of consumer-spending on economic growth independent of savings, export, investment (foreign direct investment or domestic investment), and innovation, for examples? Can a consumption-driven economy replace investment or export-driven economy? How are different theories of economic development with their respective variable(s) correlated with each other? How can such theories and variables be grouped and patterned according to their similarities or differences? The groupings and the correlations (causal or relational) between/among the variables will be the major parts of the patterns of economic growth that this study aims to explore in the Asian economy.

\section{Many Theories of Economic Growth}

Many theories and variables thereof are assumed to affect economic growth. Consumption is one of them/Consumer spending is the amount of money spent by individuals or households in an economy. Consumption is a major growth engine. One of the ways to determine how much economic growth is accomplished is to measure the GDP
(Gross Domestic Product). The GDP is based on the following formula: $\mathrm{GDP}=\mathrm{C}+\mathrm{I}+\mathrm{G}+\mathrm{NX}$, where $\mathrm{C}=$ Consumer spending; $\mathrm{I}=$ Business investments; $\mathrm{G}=\mathrm{Government}$ spending; $\mathrm{NX}=\mathrm{Net}$ exports. The equation indicates that the consumer spending is a vital part of economic growth along with capital investments (both foreign direct investment/FDI and domestic private investment), government spending, and trade (net export).

Supply-side economics is a macroeconomic theory, explaining that economic growth can be most effectively created by investing in capital and by lowering barriers on the production of goods and services. Consumers will benefit from a greater supply of goods and services at lower prices. The investment and expansion of businesses will increase the demand for employees and therefore create jobs, which also mean to increase in consumer-spending. Typical policy recommendations of supply-side economists are lower marginal tax rates and less government regulation. Investment, particularly foreign direct investment (FDI) inflow, does increase economic development of the recipient countries. This is particularly notable in developing countries where multinational corporations (MNCs) via their respective FDI are doing their businesses. A high rate of investment in the present make possible future consumer spending. A number of economists have emphasized physical investment: that is, the accumulation of structures, machinery, business plant and equipment and other tangible assets [1]. Gary [2] has emphasized the accumulation of human capital. Even physical investment is not possible or effective without the human capital.

Globalization does affect economic growth and development. There are pros and cons of the role of globalization in enhancing economic growth and quality of life. Stiglitz [3] was critical of globalization, as it has deepened global inequality between the haves and have-nots, especially in the less developed countries. Yet Goklany [4] argued for a positive effect of economic globalization via free trade, which helped to enhance human well-being. In export-driven economic growth, terms of trade (export and import) does affect economic growth. Terms of 
Page 2 of 8

trade, favorable or unfavorable, could affect economic development Favorable terms of trade, which is based on an increase in export prices relative to import prices, allows a larger volume of imports to be purchased with a given volume of exports. Thus, the favorable terms of trade imply an increase in the real purchasing power of domestic production, which is equivalent to a transfer of income from the rest of the world. They can have large impacts on consumption, savings, and investment as well. On the other hand, unfavorable terms of trade will result in a negative or low economic growth particularly in developing countries, as they rely on the export of a single or a few primary commodities $[5,6]$. Export-led growth is a trade and economic policy aiming to speed up the industrialization process of a country by exporting goods. During 1970 and 80s, the export-oriented industrialization was particularly characteristic of the development of the national economies of the Asian Tigers/Dragons: Hong Kong, South Korea, Taiwan, and Singapore ${ }^{1}$

Types of political system affect the quality of life. Democratic political system with a ' free' market- economy (economic freedom) as well as with a higher degree of political freedom enhances the quality of life. Russet [7] found that democracies, reflecting political freedom, are efficient in generating wealth and economic growth. Many developing countries have implemented liberal economic reforms in recent decades. They have been successful in economic growth (e.g., Chile, Brazil, etc.), yet there are still many other developing countries that remain poor and have not experienced any significant economic growth. While political liberalizations and reforms, with minimal corruption, are required for a sustainable economic growth, China and Singapore, for examples, with their respective 'authoritarian capitalism' have still documented a rapid economic growth without undertaking significant political liberalization. South Korea was able to rapidly develop in the 1970s and 80s while its political system still remained authoritarian. Although income distribution, equal or unequal, is affected by ethnicity, gender, or geographic region, Clemens [8] nevertheless argues that a stronger role for the state (i.e., authoritarian political system) is advantageous for equal distribution of income. And the most vulnerable members of societies can be safeguarded by the role of a stronger authoritarian government.

Stiglitz [3] argues that policies based on the Washington Consensus produce disappointing result as they are anchored in a free-market dogma, which ignores the unique socio-cultural contexts of countries where they are applied. The G20 group of governments agreed in 2010 on a 'new' Seoul Development Consensus. In contrast with the 'older' Washington Consensus, the Seoul Consensus allows a larger role for state intervention. Rather than seeking to impose a uniform top-down solution, the Seoul Consensus postulates that solutions should be tailored to the requirements of individual developing countries ${ }^{2}$.

An excessive defense spending disproportionate to economic capacity siphons off resources, which otherwise could have been used for economic development.
Sivard [9] explained that there is a trade-off between defense spending and economic growth. Based on 44 developing countries, Benoit [10] argued that there is a positive correlation between military expenditures and economic growth over the period 1950-65, which was the Cold-War period. Klare [11] also demonstrates trade- offs between the defense spending and domestic investment: every additional dollar spent on defense in developing countries reduces domestic investment by 25 cents and agricultural output by 20 cents. Barro and Robert [12] found a significant negative relationship between government consumption share and the growth of real per capita GDP. Al-Jarrah [13] examined the causal relationship between defense spending and economic growth for 1970-2003, in which he found that a higher defense spending lowered economic growth in the long run. Defense spending was still found to have a significant effect on the level of quality of life during the post-Cold war era as well. Countries with greater defense burden retain a lower quality of life regardless of population growth, urbanization and ethnic diversity [14].

Urbanization does affect consumer-spending. Urbanization based on concentrated geographic region, cities, and towns generate an aggregate demand, which increases urban consumption. The urbanization generates 'agglomeration economies' that benefit cost advantages not only to consumers but also to producers. Knowledgeeconomy/innovation economy is based on the notion that knowledge, creativity, innovation and information are the key factors of prosperity and economic development. A superior knowledge capitalization is the driving force of economic growth and productivity, which can offer a sustainable competitive advantage [15]. In the information age, the global economy moved towards the knowledge economy that spur digital as well as cybernetic economies. And the information age added knowledge-based factors to create an interconnected and globalized economy, where sources of knowledge like human expertise are crucial ingredients in economic growth. Knowledge, as embodied in human beings (as "human capital") and in technology, has always been central to economic development as well as to innovation economy.

In contrast with the knowledge-economy, a resource-based economy depends on natural resources. Alekseev and Conrad [16] show that the resource wealth has tended to make countries better off. Collier and Goderis [17] suggest that this may be due only to the income generated by resource- rents rather than the growth of output of material. They espouse both 'resource curse' and 'resource trap' theories. The curse theory suggests that countries with abundant natural resources, such as oil, often fail to democratize because the elite can live off the natural resources rather than depend on popular support for tax revenues. The trap theory argues that countries, particularly in Africa, that are dependent on oil, gas, and mining have tended to sustain weaker long-run growth, higher rates of poverty, and higher inequality of income distribution/ This is in comparison with non-oil, non-mineral dependent economies at similar levels of income.

1 The globalization based on the KOF globalization index was used in this analysis. The KOF Index of Globalization was introduced in 2002. The KOF Index of Globalization measures the three main dimensions of globalization: economic, social and political. KOF index of globalization is released annually by the KOF Swiss Economic Institute (Dreher, Gaston, and Martens).

2 The term Washington Consensus (1989) refers to market-friendly policies, which were generally advised and implemented both for advanced and emerging economies. It is also used to refer to economic reforms that were prescribed just for developing countries. In November 2010, the G20 group of governments agreed on a 'new' Seoul Development Consensus. The Seoul Development Consensus for Shared Growth is a set of principles and guidelines set up to assist the G20 nations and other global actors in working collaboratively with less developed countries in order to boost their economic growth and to achieve the UN's Millennium Development Goals (MDGs). The MDGs has been succeeded by the SDGs (Sustainable Development Goals) since 2016. 
Page 3 of 8

Some countries with natural resources are not necessarily creating the employment opportunities either. Even oil and mineral revenues have often fueled corruption, which has a severely negative impact on a country's development. Despite the wealth of natural resources, they are rather 'trapped' in poverty and unemployment, as well as in corruption.

Savings and economic growth are closely related with each other. According to the Harrod-Domar growth model, every economy must save a certain proportions of its national income. And the saving was to replace worn-out or impaired capital goods (buildings, equipment, and materials) for economic growth ${ }^{3}$. The main obstacle to economic development was a relatively low level of new capital formation, including the savings, in most poor countries [18]. Corruption distorts market, undermining development and making business unsustainable as well. Corruption means to be a lack of market transparency, which can easily have negative impact on consumer-spending. According to the World Bank, corruption increases the cost of doing business up to $10 \%$ globally ${ }^{4}$. Corruption is clearly detrimental to the global competiveness of countries. The anti-corruption crackdown could help level the playing field and will also raise foreign capital investment (inflow). Global competiveness of a country is an important determinant of economic development. The Global Competitiveness Index (GCI) measures the ability and competiveness of countries based on their respective 'national/domestic' institutions, administrations, and policies 5 . Globalization has provided an opportunity to focus global attention on previously-neglected issues such as corruption as well as the national/domestic global competiveness of countries.

The review of literature thus far indicates the following 'issues' this Asian study aims to solve: First, all the approaches to the theory of economic growth and development reviewed so far indicate that the cause/determinant of economic growth and development coalesces around a single variable (e.g., savings, investment, export, consumerspending, oil, defense spending, etc.). Based on these single-variable approaches, there is no way of identifying a 'genuine' independent effect of many an individual single variables, including the consumption, on economic growth and development. Secondly, the univariate approaches for economic growth and development might be limited in its relevance for policy guidelines in comparison with a multivariate analysis based on diverse theories and variables of economic development.

This study is based on a multivariate analysis, in which many theories and variables thereof are used simultaneously. The multivariate analysis will be based on Factor Analysis (which soon will be detailed in the 'Methodology' section below), which will identify 'factors/patterns' out of the diverse variables. It will identify a genuine independent effect of each of the variables, including consumption, on economic growth and development while taking into account the effects of other variables deemed relevant to economic growth and development. The patterns identified by the Factor Analysis could broaden and strengthen basis for serving as guidelines for policymaking for the economic development in Asia.

\section{Methodology}

The following 18 variables below were selected. This study is a crossnational comparative analysis of the 52 countries in Asia. The data cover the 2012-2016 period. Countries have different time/year for their respective data availability for each of the 18 variables during the period covered. Fifty two (52) countries/territories in Asia are used in this analysis. The cross-national (cross-sectional) comparative analysis does merit the followings. First, the benefit of a cross-sectional study design is that it allows researchers to compare many different variables at the same period of time. Since so many variables across the 52 countries in Asia are used in this study, the longitudinal analysis amenable to a few variables for a longer period of time cannot be a suitable design for this study. Second, cross-sectional studies based on many cases (countries) as well as on many variables across the countries can also sort out causal relations between the variables via statistical control, such as regression or factor analyses, for examples. This non-experimental cross-sectional design, like an experimental design, can still establish causal relations between variables via the statistical, not experimental, control. Based on the review of literature and theories, the following 18 variables were selected. Each of the 18 variables is operationalized/measured as follows:

1. Economic growth: per capita GDP PPP (Purchasing Power Parity).

2. Knowledge economy/Knowledge Economic Index (KEI): based on the following four pillars: (1) economic incentive and institutional regime, (2) education and human resources, (3) the innovation system, and (4) information and communication technology.

3. Globalization: based on the KOF Index of Globalization, which measures the three ('plural') dimensions of globalization: economic, social, and political.

4. Global competiveness/Global Competitiveness Index (GCI): measures a set of domestic institutions and policies for their respective global competiveness: The index indicates a 'national/domestic' competitiveness worldwide.

5. Terms of trade: It is calculated by dividing the value of exports by the value of imports, then multiplying the result by 100 . Favorable term of trade is over 1 , while unfavorable below 1 .

6. Corruption/Corruption Perceptions Index (CPI): annually ranks countries by the perceived levels of corruption. The CPI ranks countries on a scale from 100 (very clean/transparent) to 0 (highly corrupt/non-transparent).

3 Harrod, Roy F. (1939). "An Essay in Dynamic Theory". The Economic Journal 49 (193): 14-33. ; Domar, Evsey (1946). "Capital Expansion, Rate of Growth, and Employment". Econometrica 14 (2): 137-147.

4 The CleanGovBiz Initiative was launched under the impetus of the Declaration on Propriety, Integrity and Transparency in the Conduct of International Business and Finance (PIT Declaration), which embodies the political commitment of OECD and other adhering countries to promote clean and efficient markets and transparent governance systems. CleanGovBiz is a high priority for the OECD, as reflected in the OECD Secretary-General's 2010 Strategic Orientations, and it also responds to the political call for energetic action against corruption expressed in the G20 Action Plan Against Corruption.

5 The Global Competitiveness Report (GCR) is a yearly report published by the World Economic Forum. See World Economic Forum. Global Competiveness Index (GCI) / Global Rankings. Available on http://reports.weforum.org/global-competitivenessreport-2014-2015/rankings/ 
Page 4 of 8

7. Urbanization (\%): the measure is based on urban-rural dichotomy.

8. Types of political system/political freedom index: classified as "not free," "partly free," and "free": "not free" were coded as 1 (highly authoritarian), "partly free" as 2 (authoritarian), and "free" as 3 (democratic).

9. Military expenditure/defense spending: military expenditure as a percentage of GDP.

10. Economic freedom/Economic Freedom Index: based on trade freedom, business freedom, investment freedom, and property rights.

11. Oil (proven oil reserves/crude oil): based on countries with proven oil reserves.

12. Foreign direct investment (FDI): net inflows (new investment inflows less disinvestment).

13. Gross savings/ savings: measured by \% of GDP: A measure that accounts for both private and public savings.

14. Consumer spending/consumption: as \% of GDP.

15. Government spending: government expenditure as a percentage of GDP.

16. Tax/Tax burden: measures corporate tax burden as a percentage of GDP.

17. Domestic investment: domestic 'private' investment (physical investment) measured by $\%$ of GDP.

18. Unemployment: measured by the percent of the labor force that is without jobs.

\section{Results}

\begin{tabular}{|c|c|c|c|c|c|c|}
\hline & \multicolumn{6}{|l|}{ Patterns } \\
\hline & F1 & F2 & F3 & F4 & F5 & F6 \\
\hline & Consumption & Export & Oil & Savings & Govt Spending & Domestic Investment \\
\hline \multicolumn{7}{|l|}{ Variables } \\
\hline KEI & 0.937 & ns & ns & ns & ns & ns \\
\hline Corruption & 0.923 & ns & ns & ns & ns & ns \\
\hline $\mathrm{GCl}$ & 0.907 & ns & ns & ns & ns & ns \\
\hline Globalization & 0.906 & ns & ns & ns & ns & ns \\
\hline Consumption & 0.9 & ns & ns & ns & ns & ns \\
\hline Urbanization & 0.852 & ns & ns & ns & ns & ns \\
\hline Eco freedom & 0.849 & ns & ns & ns & ns & ns \\
\hline GDP/PPP & 0.809 & 0.462 & ns & ns & ns & ns \\
\hline FDI & 0.654 & ns & ns & ns & -0.635 & ns \\
\hline Tax/GDP & ns & -0.915 & ns & ns & ns & ns \\
\hline Terms of Trade & ns & 0.85 & ns & ns & ns & ns \\
\hline Oil & ns & ns & 0.892 & ns & ns & ns \\
\hline Pol freedom & ns & ns & -0.719 & ns & 0.421 & ns \\
\hline Defense & ns & ns & 0.485 & ns & ns & 0.472 \\
\hline Unemployment & ns & ns & ns & -0.902 & ns & ns \\
\hline Savings & ns & 0.412 & ns & 0.687 & ns & ns \\
\hline Govt Spending & ns & ns & ns & ns & ns & ns \\
\hline Domestic Invest & ns & ns & ns & ns & ns & -0.965 \\
\hline Eigenvalue \% & -42.2 & -13.8 & -13.1 & -7.9 & -6.1 & -5.8 \\
\hline
\end{tabular}

Table 1: Factor Analysis: Patterns of Economic Growth in Asia. 
Page 5 of 8

Table 1 show six factors/patterns identified. Factor 1 documents nine variables (underlined) significantly loaded: (1) KEI (knowledge economy), (2) Corruption, (3) GCI (Global Competitiveness Index), (4) Globalization (KOF index), (5) Consumption (consumer spending), (6) Urbanization, (7) Eco freedom (economic freedom), (8) GDP/PPP (economic growth), and (9) FDI (foreign direct investment/ inflow).

This cluster of nine variables underlined goes together. Factor 1 is the only factor that significantly loads consumption/consumerspending as well. Both economic growth and consumer spending are highly correlated each other, indicating the consumer-spending has positive effect on economic growth (GDP/PPP). Also the consumer spending is significantly correlated with knowledge economy (KEI), corruption, global competiveness (GCI), globalization, urbanization, and FDI/inflow respectively. This means that the knowledge- economy which is based on information, communication, technology, economic innovation and incentive are very significant and positive ingredients facilitating consumer- spending/consumption, which turns out to have positive effect on economic growth as well. Corruption was found to negatively affect consumer spending as the corruption does distort market as well. When the market is distorted, it cannot facilitate consumer- spending. A high transparency associated with a lower corruption is one of the conditions required for a free market to be efficient as well. The lower the corruption, the more the consumption. In economics, a market is transparent if much is known by many about the availability of products, services or assets. Transparency can help foreign investment/inflow as well.

FDI/inflow were also found to have significant effect on consumption. FDI/inflow by multinational corporations (MNCs) in host countries produce goods with a lower price as well as greater volume, which are favorable to the consumers. A high consumer spending is also positively associated with a high level of urbanization. Urbanization increases aggregate demands, which facilitate consumer spending.

Both globalization measured by the KOF index and the global 'competiveness' measured by the GCI (Global Competiveness Index) are not only highly correlated each other but also they are highly correlated with the consumption. The globalization by the KOF index does indicate 'international/external' world-wide interdependence and interconnectedness of a country while the global competiveness measured by the GCI (Global Competiveness Index) is based on 'national/domestic ' institutional and policy/political areas that are compatible and competitive with the global standard. Thus the global competitiveness assesses the competitiveness of 'national/domestic' competiveness worldwide: It is a set of institutions, policies, and factors that determine the level of productivity and prosperity of a country. These 'two' levels of globalization, international/external and national/ domestic, were found to have positive effects on consumption. They are mutual and significantly correlated each other. These two globalizations have also provided an opportunity to focus global attention on previously-neglected issues such as corruption (lack of transparency). Economic freedom has positive effect on consumption, indicating that a free market- economy does facilitate the consumerspending. Factor 1 is labeled as a "consumption-driven economy." Countries in Asia classified as the most/least consumption-driven economy are as follows.

[Note: The most/least is based on the factor score coefficient that is produced in descending (Most) or ascending (Least) order by the SPSS with the following formula: [factor loading (variable) $\mathrm{x}$ z-score (variable)].

MOST: Singapore, Japan, UAE, Israel, South Korea;

LEAST: Nepal, Bangladesh, Tajikistan, Pakistan, Vietnam.

Factor 2 has four variables loaded: (1) Tax (tax burden), (2) Terms of trade, (3) GDP/PPP (economic growth), and (4) Savings (gross savings).

Factor 2, like Factor 1 (consumption-driven economy), was found to load GDP/PPP (economic growth) but not Consumer (consumer spending) variables. None of the four variables, including the economic growth, was found to significantly correlate with the consumer spending. Tax as measured by the \% corporate tax of GDP indicates that a high taxation has negative effect on economic growth. A high taxation also is associated with an unfavorable terms of trade. In Factor 2, both the taxation and the terms of trade were found significant in affecting economic growth: High taxation imposed on corporate was found to result in an unfavorable terms of trade, all of which have negative effects on economic growth. Unfavorable terms of trade are clearly detrimental to the economic growth.

Yet the savings turn out to have a positive effect on economic growth. Both high taxation and unfavorable terms of trade lower the savings, which otherwise would have a positive effect on economic growth. A lower savings mean a lower economic growth. Tax burden imposed on corporates affects not only the terms of trade but also savings. Although taxation, terms of trade, and savings were found significant determinants of economic growth, none of the three variables was found to affect consumption. Unlike Factor 1 (consumption-driven economy), Factor 2 indicates that economic growth is affected not by consumption but trade (export), savings, and taxation. Factor 2 is labeled as an "export-led economy" pattern. Countries most/least classified as export-led growth economy in Asia are:

\section{MOST: Qatar, Kuwait, Macau, Singapore, Hong Kong;}

LEAST: Pakistan, Japan, India, Bhutan, Bangladesh.

(Note: One notable finding here is that Japan, classified already as one of the most 'consumption -driven economy ' countries (Factor 1), was found to be one of the least countries classified as the 'export-ledeconomy.' This means Japan must have experienced a low economic growth, unfavorable term of trade, low savings, and yet high corporate taxation during the period (2012-16) covered in this study. Although Japan was classified as one of the most 'consumption- driven economy '(Factor 1), yet it was classified as one of the least 'export -led economy 'countries. This means Japan's economic growth is still based more on the consumption-driven rather than on the export- led model).

Factor 3 loads three variables: Oil (oil richness/resources), Poli freedom (political freedom), and Defense (defense spending).

None of the three variables was found to affect economic growth or consumer spending. Oil resource and defense spending are closely associated with each other. This means that the oil-rich/resource countries in Asia are able to spend a larger amount of money in military expenditures than oil-depleted counterparts. Those oil-rich countries are also politically less democratic: They are classified as authoritarian political system. Neither the oil -richness nor the defense spending was found to affect economic growth as well as consumer spending. Oil, politics/political freedom, and defense spending were found to have no significant effects on economic growth. Both huge oil 
Page 6 of 8

resources and politics (authoritarian) affect the defense spending, which nevertheless was found to have no significant effect on economic growth. Oil-rich authoritarian government in Asia spends large revenues from oil richness/resources for defense spending. There is a significant effect of interaction between the politics (authoritarian/ democratic) and the oil resources on defense spending in Asia. Factor 3 is labeled as an "oil-rich economy" pattern. The most/least oil-rich economy countries in Asia are listed as follows:

MOST: Saudi Arabia, Russia, Iran, China, Iraq;

LEAST: Israel, Georgia, Kyrgyzstan, Tajikistan, Bangladesh.

Factor 4 has two variables loaded: (1) Unemployment and (2) Savings (gross savings). Unemployment or employment, that difference does affect savings: A higher unemployment means a lower savings, and vice versa. Clearly unemployment was found to have negative effects on savings. Yet Factor 4 indicates that the savings are based on employment/unemployment. And this 'employment-based savings' turn out to have significant effect on neither economic growth nor consumer spending. This is well contrasted with the savings in Factor 2 (export-led economy), in which the savings turn out to have positive effect on economic growth. This means the 'savings' variable is a 'cross-loading' variable. That is, the savings were found to have dual effects: In Factor 2 (export-led economy), they have shown positive effect on economic growth, but not in Factor 4. The employment-based savings' have significant effect on neither economic growth nor consumer -spending. Yet the savings generated from a lower corporate taxation as well as from a favorable terms of trade were found to have positive effect on economic growth as can be seen from the export-led economy (Factor 2). The 'savings' affected by unemployment or employment (i.e., employment-based savings) cannot afford to enhance economic growth as can be seen from Factor 4, which is labeled as an "employment-based savings economy "pattern. The most/ least "employment-based savings economy" in Asia are as follows:

MOST: Qatar, Macau, Singapore, Kuwait, China (High savings/Low unemployment);

LEAST: Afghanistan, Nepal, Armenia, Lebanon, Cypress (Low savings/High unemployment).

Factor 5 loads three variables: (1) FDI (foreign direct investment/ inflow), (2) Pol freedom (political freedom), and (3) Govt spending (government spending).
Factor 5 indicates that countries in Asia with a large government spending 'suffer' a lower FDI/inflow, and vice versa. Yet the government spending, high or low, has no significant effect on economic growth. Neither the government spending turns out to have a significant effect on consumption. It also turns out that those politically 'democratic' countries are inclined to rely more on public spending than the authoritarian counterparts. Factor 5 is labeled as a "government spending -based economy" pattern. Countries as the most/least "government spending -based economy" are:

MOST: East Timor (Timor Leste), Mongolia, Japan, Cypress, Israel (High government spending/ Low FDI inflow / High political freedom);

LEAST: Hong Kong, Singapore, Turkmenistan, UAE, Cambodia (Low government spending/High FDI inflow/Medium to Low political freedom).

Factor 6 loads two variables: (1) Domestic invest (domestic 'private' investment) and (2) Defense (defense spending). Domestic 'private' investment (physical investment) affects defense spending: The larger the domestic 'private' investment, the lower the defense spending, and vice versa. There is a trade-off between the two. Yet none of these two variables, regardless of their trade-offs, was found to have significant effect on economic growth. The defense spending, as previously shown in Factor 3 (oil-based economy), was found to have no significant effect on economic growth either. The insignificant effect of the 'domestic' investment on economic growth is quite contrasted with the 'foreign' direct investment (FDI/inflow), which was found to have significant and positive effect on economic growth as was shown in Factor 1 (consumption-driven economy). Factor 6 also shows there is no trade-off between the foreign direct investment (FDI/inflow) and domestic 'private' investment either. Factor 6 is labeled as a "domestic investment -based economy" pattern. The most/least domestic investment -based economy countries are:

MOST: China, Nepal, Indonesia, Mongolia, Kyrgyzstan (High domestic investment/Low defense spending);

LEAST: Oman, Bahrain, Pakistan, Cypress, Kuwait (Low domestic investment/High defense spending).

\begin{tabular}{|l|l|l|l|l|l|l|l|l|l|l|l|}
\hline Pattern 1 & & & & Pattern 2 & & & & Pattern 3 & \\
\hline Consumption & & & & Export-led & & & & Oil & \\
\hline Variables & B & Waldo & Sig & & B & Waldo & Sig & & B & Waldo & Sig \\
\hline KEI & 0.006 & 1.699 & 0.192 & PPP & 0 & 3.039 & 0.081 & Oil & 0.084 & 0.468 & 0.494 \\
\hline Corruption & -1.712 & 15.431 & 0 & Tax & -0.014 & 0.16 & 0.69 & Pol free & -0.844 & 7.367 & 0.007 \\
\hline GCI & 4.274 & 13.204 & 0 & TT & 0.073 & 0.286 & 0.593 & Defense & 0.022 & 2.01 & 0.156 \\
\hline Global & -0.136 & 6.418 & 0.011 & Savings & 0.11 & 14.448 & 0 & Const & 0.505 & 0.345 & 0.557 \\
\hline Consumer & 0 & 2.575 & 0.109 & Const & -2.42 & 5.727 & 0.017 & & & & \\
\hline Urb & 0.001 & 0.004 & 0.952 & & & & & & & \\
\hline
\end{tabular}




\begin{tabular}{|c|c|c|c|c|c|c|c|c|c|c|c|}
\hline Eco free & 0.074 & 1.78 & 0.182 & & & & & & & & \\
\hline PPP & 0 & 3.283 & 0.07 & & & & & & & & \\
\hline FDI & 0 & 0.149 & 0.7 & & & & & & & & \\
\hline Const & -11.537 & 5.641 & 0.018 & & & & & & & & \\
\hline Pattern 4 & & & & Pattern 5 & & & & Pattern 6 & & & \\
\hline \multirow[t]{2}{*}{ Savings } & & & & $\begin{array}{l}\text { Government } \\
\text { Spending }\end{array}$ & & & & $\begin{array}{l}\text { Domestic } \\
\text { Investment }\end{array}$ & & & \\
\hline & B & Waldo & Sig & & B & Waldo & Sig & & B & Waldo & Sig \\
\hline Variables & & & & Variables & & & & Variables & & & \\
\hline Unemp & -0.002 & 0.579 & 0.447 & FDI & 0 & 1.581 & 0.209 & Defense & 0.052 & 12.144 & 0 \\
\hline Savings & 0.071 & 9.893 & 0.002 & Pol free & -1.148 & 21.412 & 0 & Domestic invest & 0.033 & 1.572 & 0.21 \\
\hline \multirow[t]{2}{*}{ Const } & -2.29 & 11.1 & 0.001 & Gov spending & 0 & 0.002 & 0.966 & Const & -2.989 & 15.751 & 0 \\
\hline & & & & Const & 1.359 & 5.501 & 0.019 & & & & \\
\hline
\end{tabular}

Table 2: Logistic regression: uniqueness to Asian economy.

\section{Uniqueness to Asian Economy}

Table 2 presents the Logistic Regression Analysis (SPSS) of the likelihood/probability of being 'unique' to Asian economy. The table is based on a dichotomous variable, in which 222 countries in the world are divided into two groups: countries in Asia (52) are coded as 1, while the rest of the world countries as 0 . The dichotomous variable is treated as dependent variable. The uniqueness to Asian economies is based on each and every of the six patterns of the economic growth as shown in Table 1. Those variables that significantly load on each factor/pattern were treated as independent variables. And the Waldo statistics (coefficient/standard error) in Table 2 indicates the level of significance of each independent variable in contributing to the likelihood of the uniqueness. The variables significant at 0.05 level were underlined. Pattern 1 (consumption-driven economy) in Table 2 shows that Corruption, GCI (global competiveness index), and Global (globalization/KOF index) were each found to significantly differentiate in the consumption-driven economy between Asia and the rest of world. Corruption and its regression coefficient (-.1.712) indicates that the Corruption Perception Index/CPI is lower in Asia than the rest of the world: The lower the index, the more corrupt, and vice versa. This means that Asian 'economies' is perceived as having a higher corruption than the rest of the world, indicating that corruption problems are high in many countries Asia. A high corruption distorts market which can have a negative effect on consumer-spending as well.

Yet GCI (Global Competiveness Index) and its regression coefficient (4.274) is very strong for Asian economies, which is well contrasted with the rest of the world.

Despite a high 'national/domestic' global competiveness worldwide in Asian economies, 'international/external' globalization is still relatively low in comparison with the rest of the world. The regression coefficient (-.136) of Global (globalization) shows that Asian economies experience a lower level of 'international/external' globalization than the rest of the world: A low globalization was found to have a significant effect on the likelihood of Asian economy. Despite a low 'international/external' globalization,' Asian countries have a strong 'national/domestic' global competiveness worldwide as measured by GCI, which was found to have significant effect on the likelihood of Asian economy.

In Pattern 2 (export-led economy)/Table 2, Savings and its regression coefficient .110 indicates that a high savings were found to have significant effect on the likelihood of Asian economies. Asian economy is rather 'unique' in that a large savings play an important role in contributing to economic growth as was shown in the 'exportled growth economy' pattern in Asia.

In Pattern 3 (oil-based economy)/Table 2, Pol free (political freedom) was found significant along with its large regression coefficient (-.844). This means that a significant effect of the politics on the 'trade-offs' between oil-resources and defense spending are conspicuous in Asia, which differentiates Asia from the rest of the world: The effect of 'politics' on the oil-based economy is significant in the Asian economy. Authoritarian political system is more likely to be able to 'utilize' the oil-richness for a large defense spending purpose than democratic counterparts in Asia. Yet none of the two 'nonpolitical 'variables of the oil-based economy, defense spending and oilresources, was found to have significant effects on the likelihood of being Asian economy only. This means that the positive effect of the oil-resources on the defense spending as was addressed in the patterning of the oil-rich economy (see Table 1/Pattern 3) is rather universal, Asia or the rest of the world. Yet in the Asian economy, politics was found to have significant effect on the oil-based economy, which is different from the rest of the world.

In Pattern 4 (saving-based economy)/Table 2, Savings and its regression coefficient (.071) indicate that a high savings was found to have significant effect on the likelihood of Asian economy. The savings was also found significant in the export-led economy (Pattern 2/Table 2). Yet the savings in Pattern 4 indicates an 'employment-based savings' as was previously discussed. Despite its insignificant effect on economic growth, the employment-based savings turn out to have significant effect on the likelihood of Asian economy. This means the savings, whether in the export-led economy or in the employment- 
Page 8 of 8

based savings economy, whether it has a significant effect on economic growth or not, has nevertheless significant effect on the likelihood of being Asian economy. That is, a high savings features 'uniqueness' to the Asian economies.

In Pattern 5 (government spending- based economy)/Table 2, Pol free (political freedom) variable along with its regression coefficient $(-1.149)$ was found significant: This means that authoritarian political system/politics has a significant effect on the likelihood of Asian economies in comparison with the rest of the world economy. In Asian economy, differences between authoritarian and democratic governments means the differences in government spending. It was already shown that politics (authoritarian government) plays a significant role in the oil-based economy (Pattern 3/Table 2), which is rather 'unique' to the Asian economy as well.

In Pattern 6 (domestic investment -based economy)/Table 2, the Defense (defense spending) along with its regression coefficient (.052) indicates that a large defense spending has a significant effect on the likelihood of the Asian economy. Yet a larger defense spending means a smaller domestic investment. And these trade-offs between the 'defense spending' and the domestic 'private' investment is very conspicuous in Asia, distinguishing Asia from the rest of the world economy.

\section{Conclusion}

Patterns of Asian economic growth were found diverse, yet there were some features 'unique' to the Asian economies as well, which is distinguished from the rest of the world. Six patterns of Asian economic growth were identified: consumption-driven; export-led; oilrich/resources; employment saving-based; government spending; and domestic investment. The consumption-driven economy is the most predominant pattern of Asian economic growth. Both the consumption-driven and the export-led economies were found significant in positively affecting economic growth, while oil-resources, employment based-savings, government spending, and domestic investment not. In its effects on economic growth, the consumptiondriven economy is not uni dimensional solely based on the consumerspending. It was found multidimensional beyond a singular consumer spending variable. The consumption is significantly affected by knowledge economy, globalization, global competiveness, economic freedom/free market system, urbanization, a low corruption (a high transparency), and foreign direct investment (FDI) inflows. And the knowledge-economy based on innovation, information, and technology, was found the strongest of all in increasing consumerspending.

The six patterns of economic growth found in Asia are commonly shared with the rest of the world economy as well, yet there were some 'uniqueness' to the Asian economy, which features as follows: (1) high savings; (2) a large defense spending affected by oil-richness as well as by politics (authoritarian government) (3) a high 'national/domestic' global competiveness worldwide despite a relatively low 'international/ external' globalization. (4) A high corruption which distorts market.
The significant effect of consumption-driven economy on economic growth based on its multidimensionality might deserve it to alter, if not replace, investment, export, and savings-driven economic growth models respectively. Yet the latter three 'economic growth models' were still found to have significant and positive effects on economic growth 'independent' of the consumption-driven growth model. Empirical evidences, however, shows that the dominance of the consumptiondriven economic growth model in Asia cannot be denied. And any negative 'uniqueness' to Asian economy should be reassessed in light of the 'multidimensionality' of successful consumption-driven economic growth model as empirically proven in Asia as well.

\section{References}

1. De Long J, Bradford, Lawrence H, Summers (1991) machinery and equipment investment has a strong association with growth, adding that it was much stronger than found between growth and any of the other components of investment. The Quarterly Journal of Economics 106: 445-502.

2. Gary SB (1993) Human Capital (3r edn.), The University of Chicago.

3. Stiglitz J (2003) Globalization and Its Discontents. New York: W.W.Norton \& Compan, pp: 1-282.

4. Goklany IM (2007) The Improving State of the World: Why We're Living Longer, Healthier, More Comfortable Lives on a Cleaner Planet. Cato Institute, pp: 1-516.

5. Chow PCY (1987) Causality between Export Growth and Industrial Development: Emperical evidence from the NICs. Journal of Development Economics 26: 55-63.

6. Francis C (2008) International Economics (5th edn.), McGraw-Hill Irwin, pp: 443-451.

7. Russet B (2005) Bushwhacking the Democratic Peace. International Studies Perspective 6: 395-408.

8. Clemens MA (2007) Smart Samaritans. Foreign Affairs, pp: 132-140.

9. Sivard RL (1991) World Military and Social Expenditures. World Priorities. Washington DC, 14: 1-17.

10. Benoit E (1978) Growth and Defense inn Developing Countries. Economic development and Cultural Change 26: 1-271.

11. Klare MT (1987) The Arms Trade: Changing Patterns in the 1980s. Third World Quarterly 9: 1257-1281.

12. Barro, Roberet J (1990) The Journal of Political Economy. Government Spending in a Simple Model of Endogenous Growth 125: 1.

13. Al-Jarrah AA (2005) Defense Spending and Economic Growth in an OilRich Country: The Case Of Saudi Arabia. Pakistan Economic And Social Review 43: 151-166.

14. Kim HS (1996) Trade-Offs between Military Spending, Quality of Life and Economic Growth, Comparative Economic Studies 38: 69-84.

15. Tocan, Madalina Cristina (2012) Knowledge Based Economy Assessment. Journal of Knowledge Management, Economics and Information Technology 2: 1-14.

16. Alexeev Michael, Robert Conrad (2009) The Elusive Curse of Oil. Review of Economics and Statistics 91: 586-598.

17. Collier Paul, Benedikt Goderis (2007) Commodity Prices, Growth, and the Natural Resource Curse: Reconciling a Conundrum. Centre for the Study of African Economies, University of Oxford.

18. Rostow WW (1960) The Stages of Economic Growth: A non-communist manifesto. Cambridge University Press, pp: 4-16. 